\title{
Pollution and Siltation of Rivers in the Western Highlands of Cameroon: a Consequence of Farmland Erosion by Runoff
}

\author{
Henri Grisseur Djoukeng (PhD Candidate)
}

University of Liège Gembloux Agro-Bio Tech, Department of Science and Environmental

Technology, Soil-Water Systems Unit, Gembloux, Belgium, djhgrisseur@yahoo.fr

\section{Christopher Mubeteneh Tankou (Lecturer)}

University of Dschang, Cameroon, Faculty of Agronomy and Agricultural Sciences, cmtankou@yahoo.com

\section{Aurore Degré (Professor)}

University of Liège Gembloux Agro-Bio Tech, Department of Science and Environmental Technology, Soil-Water Systems Unit, Gembloux, Belgium, aurore.degre@ulg.ac.be

\author{
Written for presentation at the \\ (21st Century Watershed Technology Conference and Workshop: \\ Improving Water Quality and the Environment) \\ (The University of Waikato) \\ (Hamilton, New Zealand) \\ (3 - 7 November 2014)
}

\begin{abstract}
Water is one of the most important natural resources in maintaining the balance of global ecosystems. Water is the engine of life but she can also devastate. Subject of controversy, lusts, strategic issues, water is currently raising awareness of the need to preserve this precious commodity which directly affects food security, socioeconomic development and health. Sustainable management and protection of water resources must then involve all social strata. In one community, water is the source of life, source of peace, source of development, but it can also be a main source of conflict and instability. The western highlands of Cameroon are an agro-ecological zone of high population density and rapid population growth. In this area where land tenure is quite complex, farmers cultivate steep slopes (> 25\%) for the production of vegetable crops. In order to facilitate the turning of the land, these farmers prepare seedbeds flat or forming ridges along the steepest slope, two methods of land preparation that do not include any measure of water conservation. With these methods of land preparation favouring runoff, pesticides and fertilizers applied in cultivated plots are transported by runoff or transfer of sediments to rivers; this transfer negatively affects an agricultural function which is environmental protection therefore water. To establish liability of agricultural practices in pollution and siltation of rivers, we studied a section of the main river of Méloh watershed whose width varies between 2 and $3.5 \mathrm{~m}$ on a twisty length of $300 \mathrm{~m}$. This study showed that tied


ridging reduced siltation of rivers by $72 \%$; so this is an effective technique to fight against water pollution in mountain agriculture.

Keywords: Pollution, siltation, watershed Méloh, water, Cameroon

The authors are solely responsible for the content of this technical presentation. The technical presentation does not necessarily reflect the official position of the American Society of Agricultural and Biological Engineers (ASABE), and its printing and distribution does not constitute an endorsement of views which may be expressed. Technical presentations are not subject to the formal peer review process by ASABE editorial committees; therefore, they are not to be presented as refereed publications. Citation of this work should state that it is from an ASABE conference presentation. (Conference Name). EXAMPLE: Author's Last Name, Initials. 2010. Title of Presentation. 10xxxx. St. Joseph, Mich.: ASABE. For information about securing permission to reprint or reproduce a technical presentation, please contact ASABE at rutter@asabe.org or 269-932-7004 (2950 Niles Road, St. Joseph, MI 49085-9659 USA). 


\section{Introduction}

Water is one of the most important natural resources in maintaining the balance of global ecosystems; it directly affects food security, socioeconomic development and health. Sustainable management and protection of water resources are not only technical, but they are first and foremost social and economic; these aspects must then involve all social strata. In one community, water is the source of life, source of peace, source of development, but it can also be a source of conflict and instability. The western highlands of Cameroon are an agroecological zone of high population density and rapid population growth. In this area where land tenure is quite complex, farmers cultivate steep slopes (>25\%) for the production of vegetable crops. In order to facilitate the turning of the land, these farmers prepare seedbeds flat or forming ridges along the steepest, two methods of land preparation that do not include any measure of water conservation. With these methods of land preparation favouring runoff, pesticides and fertilizers applied in cultivated plots are transported by runoff or transfer of sediments to rivers; this transfer negatively affects an agricultural function which is environmental protection therefore water. In the rural areas of western highlands as in all rural areas of Cameroon, rivers are the main source of household drinking water; it is in these same rivers that people do laundry and cleaning phytosanitary treatment equipment. For ten years we see the irregular flow of rivers in the watershed Méloh and the progressive deterioration of the quality of their waters. Faced with this alarming situation adds to the observed climate changes around the world, we experimented with the cultivation of the potato tied ridging in the fight against erosion by runoff; its effectiveness was tested by comparing the amounts of runoff and sediment obtained from three types of land preparation, namely the flatbed, ridging along the steep slope and tied ridging. To establish liability of agricultural practices in pollution and siltation of rivers, we studied a section of the main river of Méloh watershed whose width varies between 2 and $3.5 \mathrm{~m}$ on a twisty length of $300 \mathrm{~m}$; this section was isolated from sediment from upstream and the water flowing over the rocks to sediment deposition in an inactive natural well measuring $0.90 \mathrm{~m}$ deep, $3 \mathrm{~m}$ long and $2.5 \mathrm{~m}$ wide and rocky bottom. A natural well receives heterogeneous sediments from both sides covering a total area of approximately 7.5ha. The two sides have fairly regular slopes of 14 and $17 \%$ cultivated on $150 \mathrm{~m}$ from the ridge on the one hand and on $100 \mathrm{~m}$ the other hand. Since the year 2012, the well is checked after each rain and measurements were taken at regular time intervals for three years. Sediments collected are several types (land, plant debris, packaging of pesticides and plastic sheaths for irrigation) and measures relate specifically to the physical characterization, quantities and their evolution in space and time.

Water is the engine of life but she can also destroy, devastate, flood. Subject of controversy, lusts, strategic issues, water is currently raising awareness of the need to preserve this precious commodity. To use water more efficiently and protect, it must be better studied (Touchart 2003). The latest river's studies conducted in Cameroon back to the 80s (Olivry 1986); these studies have focused primarily on the assessment of river flows without reference to those factors involving their failures, like local agricultural practices in the hills.

The overall objective of this study is to assess the impact of local agricultural practices on siltation of the river. To achieve our goal, we went through two specific objectives:

1. to characterize and quantify sediment that migrate from cultivated plots to the bed of the river;

2. to provide a comparative analysis of sediments from each of three methods of soil preparation. 


\section{Materials and Methods}

\subsection{Study area}

The experiment was conducted in the village of Méloh in Fongo-Tongo subdivision (Fig. 1) found between the geographical coordinates $5^{\circ} 27^{\prime}-5^{\circ} 37^{\prime} \mathrm{N}$ and $9^{\circ} 57^{\prime}-10^{\circ} 05^{\prime} \mathrm{E}$ (ECAM3 2008). This village is one of the largest sites of potato production in the western highlands of Cameroon which is the main production area of foodstuff in the Central Africa subregion(PAFPT 2004).

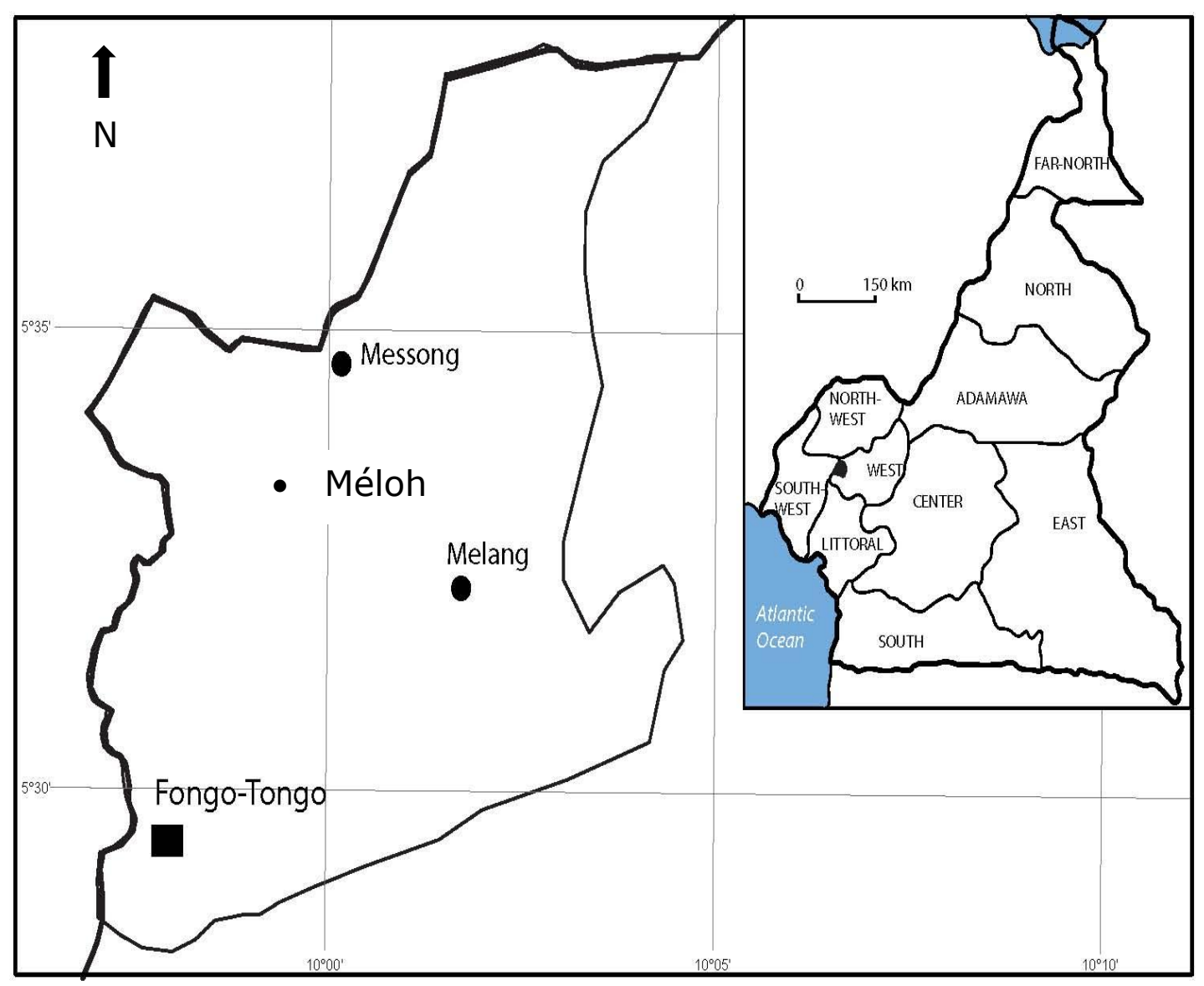

Figure 1: Geographical location of research site 


\subsection{Climatic data of the study area}

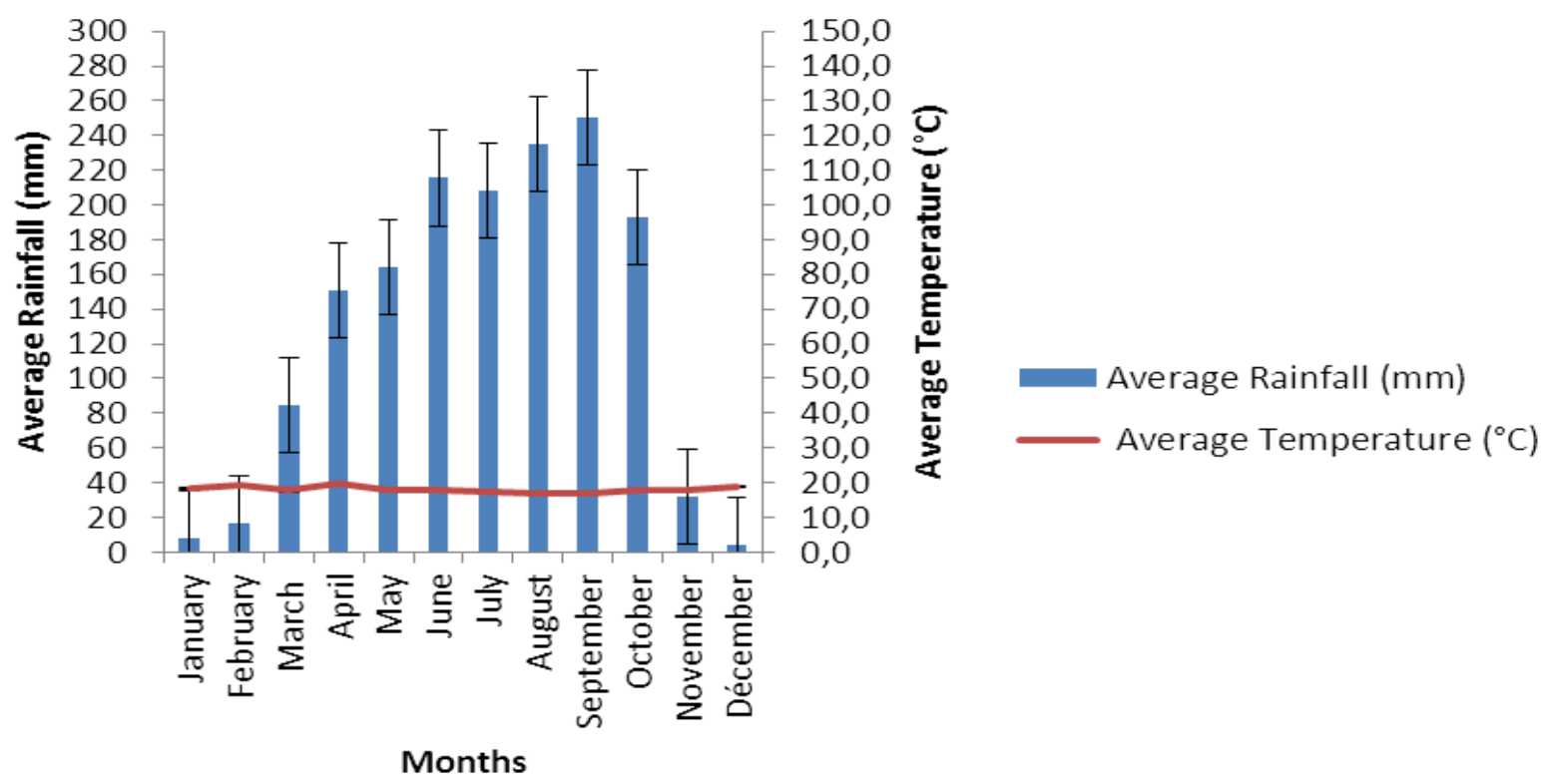

Figure 2: Climate data from the research site

\subsection{Hydrography of the study area}

Watershed Méloh is crossed by several rivers that originate in the Bamboutos mountains and are appointed by the names of the villages.

\subsection{Data collection}

The collected and measured sediments consist of land, plant residues and other (pesticides packaging, leftover sheaths for irrigation and food packaging). These sediments are dried and weighed with a scale of $50 \mathrm{~kg}$ maximum capacity.

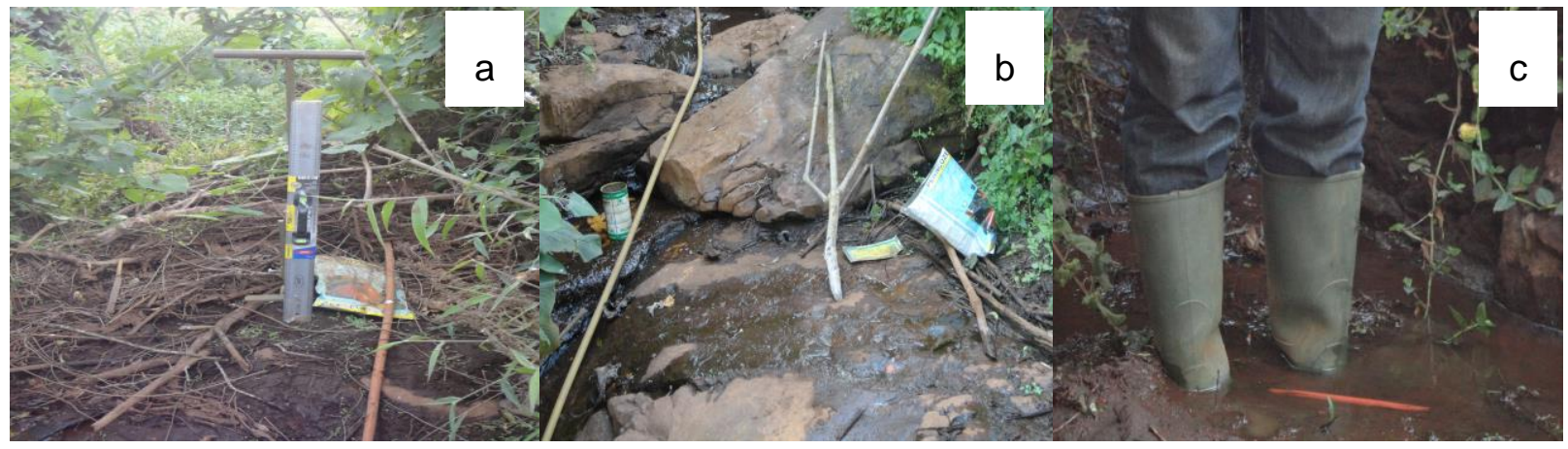

$\mathrm{a}=$ Well 7 days after the rain

$\mathrm{b}=$ well immediately after rain during full vegetative cover

$\mathrm{C}=$ well immediately after rain during weeding and hoeing

Figure 3: Presentation of the sediments collection well 


\section{Results and Discussion}

Table 1: Total quantities of sediment per year

\begin{tabular}{lrrr}
\hline & 2012 & 2013 & 2014 \\
\hline Land $(\mathrm{t})$ & 3,5 & 4,1 & 1,5 \\
Plant residues $(\mathrm{t})$ & 0,127 & 0,092 & 0,08 \\
Other ( $\mathrm{t}$ ) & 0,012 & 0,017 & 0,005 \\
TOTAL & 3,639 & 4,209 & 1,585 \\
\hline
\end{tabular}

Table 1 shows that during the 2012 and 2013 crop years which tied ridging were not implemented by farmers, outstanding deposit of sediment in the river have increased from 3.6 to 4.2 metric tons. During the 2014 crop year during which $75 \%$ of farmers have adopted tied ridging, quantities of sediment decreased from 4.2 to 1.6 metric tons, a remarkable $72 \%$ reduction in siltation of rivers.

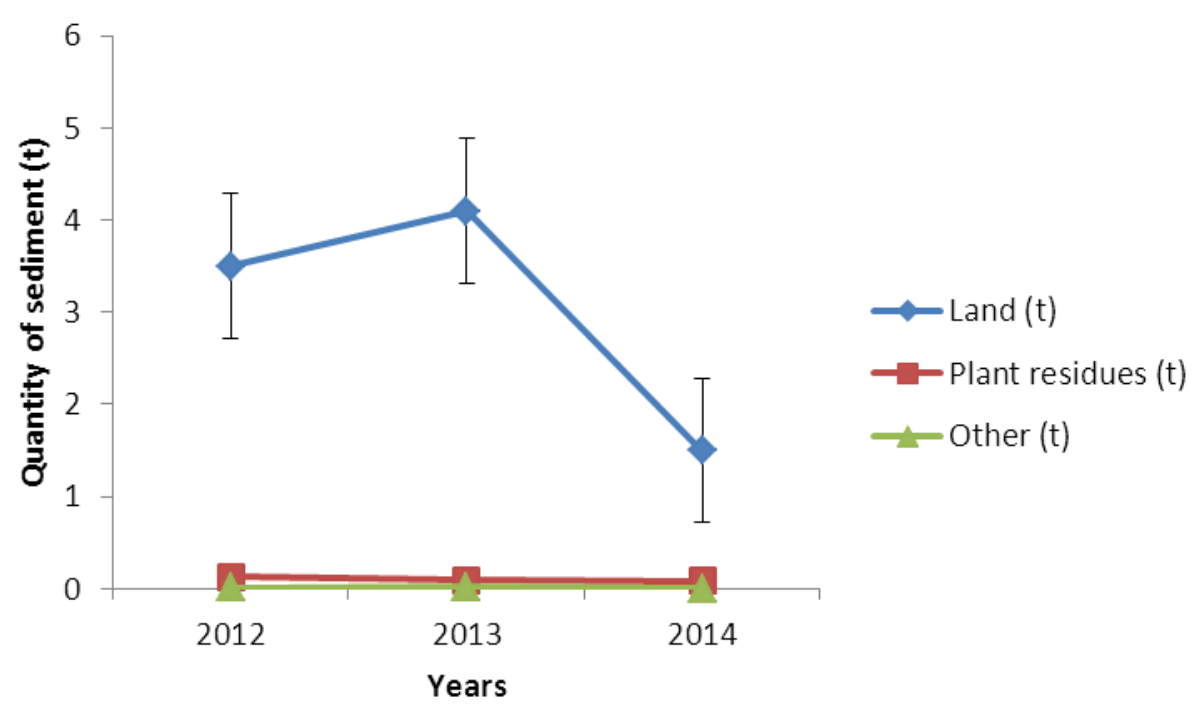

Figure 4: Evolution of different sediment amounts over time

During the 2012 and 2013 crop years which tied ridging was not implemented by farmers, the deposit of land in the river have increased from 3.5 to 4 metric tons, the deposit of plant residues have increases from 0.127 to 0.092 metric ton, and the deposit of other sediments have increased from 0.012 to 0.017 metric ton. During the 2014 crop year during which $75 \%$ of farmers have adopted tied ridging, the amount of land decreased from 4 to 1.5 metric tons, a $73 \%$ decrease of land in the river; the amount of plant residues decreased from 0.092 to 0.08 metric ton, a $53 \%$ decrease of plant residues in the river; and the amount of other sediments decreased from 0.017 to 0.005 metric ton, a $77 \%$ decrease of other sediments in the river (Figure 4). Note that the decrease in the amounts of other sediments (pesticides packaging, leftover sheaths for irrigation and food packaging) is not only the result of tied ridging but also awareness made to farmers who do not throw their packages in the river; other plant residues arrive in the well under the influence of wind. 


\section{Conclusion}

The average length of stay of water in rivers being only a few days (Giret 2007), as the populations of the study area depending exclusively on river water, our challenge is to find ways and means to preserve its quality. This study has shown that tied ridging is a solution against river pollution in the context of mountains agriculture; its high contribution $72 \%$ reduction in siltation of rivers leads us to recommend it to all farmers exploiting hills concerned about the sustainable conservation of natural resources. In our future works we would do a general study of rivers in watershed Méloh over their entire length (hydrograms construction and chemical analyzes of water); awareness and environmental education must remain appropriate.

\section{References}

Anctil, F., J. Rousselle, and N. Lauzon. 2012. Hydrologie: Cheminements de l'eau: Presses inter Polytechnique.

Cosandey, C., and M. Robinson. 2012. Hydrologie continentale: Armand Colin.

ECAM3. 2008. Enquête camerounaise sur les ménages. Rapport du Ministère de l'Agriculture et du Développement Rural.

Freeze, R. A., and J. A. Cherry. 1979. Groundwater. Prentice-Hall.

Giret, A. 2007. Géographie de l'écoulement fluvial: L'Harmattan.

Maidment, D. R. 1993. Handbook of hydrology: McGraw-Hill.

Martin, H. 2010. Introduction to Physical Hydrology.

Olivry, J. C. 1986. Fleuves et rivières du Cameroun. Paris: ORSTOM; MESRES.

PAFPT. 2004. Programme d'Appui à la Filière Pomme de Terre. Projet PPTE.

Petretti, F. 1997. Fleuves et rivières. Naturoscope ed. Paris: Naturoscope Gründ.

Touchart, L. 2003. Hydrologie. Mers, fleuves et lacs: Armand Colin.

Ward, R. C., and M. Robinson. 1990. Principles of hydrology. London: McGraw-Hill Book Company. 